\title{
BMJ Open Global systematic review of Indigenous community-led legal interventions to control alcohol
}

\author{
Janani Muhunthan, ${ }^{1,2}$ Blake Angell, ${ }^{1,3}$ Maree L Hackett,, ${ }^{1}$ Andrew Wilson, ${ }^{2,4}$ \\ Jane Latimer, ${ }^{1}$ Anne-Marie Eades, ${ }^{1}$ Stephen Jan $^{1,6}$
}

To cite: Muhunthan J, Angell B, Hackett ML, et al. Global systematic review of Indigenous community-led legal interventions to control alcohol. BMJ Open 2017;7: e013932. doi:10.1136/ bmjopen-2016-013932

- Prepublication history and additional material is available. To view please visit the journal (http://dx.doi.org/ 10.1136/bmjopen-2016013932).

Received 19 August 2016 Revised 25 November 2016 Accepted 17 January 2017

\section{(a) CrossMark}

\author{
${ }^{1}$ The George Institute for \\ Global Health, Sydney, \\ Australia \\ ${ }^{2}$ The Australian Prevention \\ Partnership Centre, Australia \\ ${ }^{3}$ The Poche Centre for \\ Indigenous Health, Sydney \\ Medical School, University of \\ Sydney, Sydney, Australia \\ ${ }^{4}$ Menzies Centre for Health \\ Policy, University of Sydney, \\ Sydney, Australia \\ ${ }^{5}$ The University of Central \\ Lancashire, Preston, UK \\ ${ }^{6}$ Sydney Medical School, \\ University of Sydney, \\ Australia
}

Correspondence to Janani Muhunthan; jmuhunthan@georgeinstitute. org.au

\section{ABSTRACT}

Objectives: The national and subnational governments of most developed nations have adopted cost-effective regulatory and legislative controls over alcohol supply and consumption with great success. However, there has been a lack of scrutiny of the effectiveness and appropriateness of these laws in shaping the health-related behaviours of Indigenous communities, who disproportionately experience alcohol-related harm. Further, such controls imposed unilaterally without Indigenous consultation have often been discriminatory and harmful in practice.

Setting, participants and outcome measures: In this systematic review of quantitative evaluations of Indigenous-led alcohol controls, we aim to investigate how regulatory responses have been developed and implemented by Indigenous communities worldwide, and evaluate their effectiveness in improving health and social outcomes. We included articles from electronic databases MEDLINE, EMBASE, CINAHL, PsycINFO and Web of Science from inception to December 2015.

Results: Our search yielded 1489 articles from which 18 met the inclusion criteria. Controls were implemented in rural and remote populations of highincome nations. Communities employed a range of regulatory options including alcohol rationing, prohibition of sale, importation or possession, restrictions on liquor sold, times of sale or mode of sale, Indigenous-controlled liquor licensing, sin tax and traditional forms of control. 11 studies reported interventions that were effective in reducing crime, injury deaths, injury, hospitalisations or lowering per capita consumption. In six studies interventions were found to be ineffective or harmful. The results were inconclusive in one.

Conclusions: Indigenous-led policies that are developed or implemented by communities can be effective in improving health and social outcomes.

\section{INTRODUCTION}

Governments in most developed nations have adopted some form of regulatory and legislative control over alcohol supply and consumption through initiatives such as licensing systems, taxation, a minimum age

\section{Strengths and limitations of this study}

- This systematic review is the first to explore the effectiveness of legal responses to alcohol misuse and alcohol-related harm that have been designed and implemented by Indigenous communities.

- Summarising the evidence on effective and ineffective community-led policy models could provide valuable insights into local policy innovation to promote the health of marginalised populations.

- Effective controls could encourage nation-states and subnational governments to facilitate, through a menu of regulatory instruments, powerful and acceptable community-led approaches to Indigenous alcohol policy worldwide.

- This review was limited to published literature and did not include grey literature.

of purchase and penalties for drink drivers. These measures have proven beneficial to the health of populations worldwide, however, Indigenous communities across the world remain disproportionately affected by harmful alcohol use, casting doubt over the effectiveness of these measures in reducing the burden of alcohol-related deaths, chronic disease and disability in Indigenous populations. There have been limited evaluations of the effectiveness of such legal measures and their appropriateness in shaping alcohol-related behaviours in Indigenous communities.

In part, the disproportionate burden of alcohol harm borne by Indigenous communities around the world has resulted from the stressful experiences of discrimination, colonialism, dispossession and economic and social marginalisation of Indigenous peoples in many countries. ${ }^{1}{ }^{2}$ Public health academics hypothesise that legal measures may be ineffective in reducing this burden in Indigenous populations because policy models lack cultural acceptability, due to 
inadequate investment in the social determinants of health (eg, education, transport and employment) and that these policies fail to achieve adequate levels of enforcement and accountability in these communities. ${ }^{3}{ }^{4}$ The United Nations (UN) Expert Mechanism on the Rights of Indigenous Peoples has mandated that Indigenous participation in decision-making on the full spectrum of matters that affect their lives forms the fundamental basis for the enjoyment of human rights. ${ }^{5}$ Further, the UN has cautioned member states that a failure to ensure these rights can lead to further marginalisation and inequities among Indigenous people. ${ }^{5}$ Yet peak Indigenous health bodies such as Australia's National Aboriginal Community Controlled Health Organisation attribute the ongoing crisis in Indigenous health to a lack of cohesive public policy and the lack of power that Indigenous people have had in influencing public policy decisions that affect their social and emotional and well-being. ${ }^{6}$ In Australia, public health academics have argued that compulsory alcohol restrictions which have been imposed on Indigenous communities by unilateral state action (in some areas for decades), have constituted "an affront to Indigenous self-determination" and that without community support, these interventions are "an overly simplistic solution to a complex problem" and risk the revival of a protectionist past. $^{7}$ In the USA, following a move to nullify local alcohol laws established by Alaska Native tribal councils by the Federal Government, alcohol abuse and alcohol-related mortality escalated for the next two decades until this centralised approach was reversed. ${ }^{8}$

Local Indigenous knowledge and systems of governance, which could provide insights into policy innovation and a sustainable shift in social norms, remain neglected areas of public health research to date. There is potential for community-led legal initiatives to be used as preventative health tools for communities affected by the harmful use of alcohol and disproportionately affected by chronic conditions and their risk factors. While community leadership is the ideal, it is not always clear how this concept is applied, in particular how community involvement in the design and enforcement of these programmes interacts with formal government regulatory input. Such community input could involve the engagement of local leaders in developing local solutions through innovative initiatives that use tools such as community partnerships, local taxes, restrictions or incentives. Lessons regarding the use and effectiveness of such measures have not been synthesised previously in the published literature. In light of emerging interest in building countries' legal infrastructure to promote health, this study aimed to investigate how Indigenous communities use public health law mechanisms to control alcohol and prevent its misuse and to what extent controls are effective in achieving improvements in health and social outcomes. $^{9}$

\section{METHODS}

A systematic review of published literature was undertaken. Databases MEDLINE, EMBASE, CINAHL, PsycINFO and Web of Science, were searched from inception to 18 December 2015 to identify published quantitative evaluations of Indigenous-led alcohol controls. The WHO definition was followed in identifying Indigenous populations. ${ }^{10}$ Globally, there is a lack of consensus regarding the terminology used to describe Indigenous populations. In this review, we have mirrored the study authors' use of Indigenous terminology.

\section{Inclusion criteria}

Studies had to meet four criteria for inclusion in this review. First, studies had to examine an Indigenous population. The search strategy (see online supplementary file 1) for this component was adapted from previously published systematic reviews. ${ }^{11}{ }^{12}$ Second, studies had to examine legal interventions (including traditional forms of law) that were community-led. The authors defined community-led in terms of development and/or implementation (either in terms of development and/or implementation). In order to be included on the basis of development, communities needed to have developed (in isolation or in collaboration with other stakeholders such as governments) the nature and scope of the alcohol control. To be included on the basis of implementation, it was necessary that alcohol controls were implemented or governed by the community or community representatives. Studies were included if controls were governmentfacilitated with supporting regulatory controls. The authors acknowledge that regulatory responses to control alcohol often require the resources and regulatory power of governments and their agencies. Therefore, it is open to conjecture whether these controls can be genuinely community led. Third, studies had to examine interventions designed to reduce the harms of alcohol consumption. Finally, studies had to quantitatively evaluate the effectiveness of legal interventions to control alcohol in improving one or more health or social outcomes. Qualitative articles, as they lacked a quantitative measure of effectiveness, were excluded from this review. Studies were not excluded on the basis of language, the methods of the quantitative studies or their outcome measures.

\section{Data extraction}

Study review and selection were independently undertaken by two authors (JM and BA). Abstracts, titles and keywords of the studies returned from the search were screened for compatibility with the inclusion criteria. Once studies were identified for potential inclusion, full texts were reviewed. Reference lists of included papers were independently reviewed by two authors (JM and BA) for studies that may warrant inclusion. Data were extracted from the studies using a form developed for the review in consultation with the authorship team. 
Data extracted included country of origin, Indigenous population and size, category of alcohol control, legal instruments employed, communities' use of research evidence or population data to inform the control, data collected and time horizon of the evaluation (table 1). Any disagreements throughout this process were resolved by arbitration with reviewers MLH and SJ.

\section{RESULTS}

The review found 18 studies spanning 1975 to 2014.

\section{Populations studied}

All studies came from high-income nations, the USA $(n=10)$, Australia $(n=6)$, Canada $(n=1)$ and Greenland $(n=1$; see table 2). Except for the Greenlandic study which was nationwide, populations studied were rural or remote communities.

\section{Study designs}

All study designs were of before and after, cross-sectional or time-series analyses using primarily secondary data (table 2). Two of the included Australian studies are linked before and after studies evaluating the impact of alcohol controls in four communities following the introduction of two state government-facilitated supply-reduction strategies, one in 2002-2003 and the other in $2008 .^{13} 14$

Eight studies evaluated health or social outcomes before and after alcohol controls were introduced. ${ }^{13-20}$ Two of those studies also evaluated health or social outcomes after the controls were repealed in their study populations. ${ }^{19} 20$

Six studies used one or more other populations as a control group to compare 'wet' villages (those without a restrictive alcohol law) with 'damp' villages (those with some restrictions in place but where alcohol could still be bought in specific containers, quantities and venues) or 'dry' villages (those with laws prohibiting the availability of alcohol). 817 21-24

Two studies from the US compared health outcomes between one or more communities with different forms of governance of alcohol control. ${ }^{25}{ }^{26}$ One compared traditional forms of control with communities that had implemented local option laws (government-facilitated opt-in alcohol controls that could be voted in by residents via local referendum). ${ }^{25}$ The other compared outcomes between communities that had alcohol prohibited under federal law, state law and local option laws. ${ }^{26}$ One study compared Native and non-Native American populations. ${ }^{27}$

One study evaluated a package of Indigenous-led interventions implemented at different points in time and used a time-series analysis to evaluate health and social outcomes. ${ }^{28}$ Three studies employed a comparison of Indigenous communities and state or national averages across health and social outcomes. ${ }^{17} 2829$ In their use of comparators, some studies fell into more than one of the categories discussed above.

\section{Time horizon of evaluation}

The length of follow-up investigations ranged between 1 and 27 years (table 2 ).

\section{Categories of alcohol control}

A range of regulatory options were designed and implemented by local communities (table 2). The majority of controls involved prohibition of the sale, importation or possession, restrictions on liquor sold, times of sale or mode of sale, Indigenous-controlled liquor licensing and enhanced law enforcement. Other forms of regulatory control included a local excise tax, alcohol rationing and traditional forms of control. Under Greenland's alcohol rationing system, each individual was entitled to a sheet of 72 points of rationing coupons per month. Alcohol was priced according to strength or size of alcohol purchase (eg, one point for one beer and 24 points for three-quarters of a litre of hard liquor)..$^{20}$ Traditional forms of control were observed in Alaskan communities where the 'Yupi'it Nation' sovereignty movement (in opposition to government-facilitated local option laws) had gained popularity. Interventions involved a range of group-oriented responses including ignoring antisocial behaviour, presenting the transgression in a dramatised dance form in the men's house (kashgi), community leaders resolving the dispute through consultation, banishment from the village and finally, killing the offender. ${ }^{25}$

\section{Indigenous representation in decision-making}

Indigenous-led controls reviewed fell into four categories. First, controls that were conceived and implemented by the community included the traditional forms of control discussed previously. ${ }^{25}$ Second, government-

Table 1 Data extracted from evaluations meeting inclusion criteria

\begin{tabular}{llll}
\hline Population & Characteristics of evaluation & Mechanism of alcohol control & Effectiveness of control \\
\hline Indigenous population & Study design & Type of alcohol control mechanism & Outcomes reported \\
Country of origin & Time horizon of evaluation & Legal instruments employed & Effectiveness of control in \\
$\begin{array}{ll}\text { Setting (urban or remote) } \\
\text { Size of study population }\end{array}$ & Use of control population & Use of research evidence and & achieving prevention \\
& $\begin{array}{l}\text { Study limitations } \\
\text { Generalisability of findings }\end{array}$ & $\begin{array}{l}\text { population data to inform scope and } \\
\text { nature of control }\end{array}$ & \\
& Policy implications & & \\
\hline
\end{tabular}




\begin{tabular}{|c|c|c|c|c|c|c|c|}
\hline $\begin{array}{l}\text { Author } \\
\text { (year) }\end{array}$ & $\begin{array}{l}\text { Country of } \\
\text { origin } \\
\text { (Indigenous } \\
\text { population) }\end{array}$ & Population size & $\begin{array}{l}\text { Category of alcohol } \\
\text { control }\end{array}$ & Legal instruments & $\begin{array}{l}\text { Health and social } \\
\text { outcomes reported }\end{array}$ & Data collected & $\begin{array}{l}\text { Time Horizon of } \\
\text { evaluation }\end{array}$ \\
\hline May $(1975)^{19}$ & $\begin{array}{l}\text { United States } \\
\text { (Native American) }\end{array}$ & 12000 (Native American) & $\begin{array}{l}\text { Prohibition of sale, } \\
\text { importation or possession }\end{array}$ & $\begin{array}{l}\text { Tribally imposed } \\
\text { prohibition laws }\end{array}$ & Arrests & Tribal Police data & $\begin{array}{l}3 \text { years (June-July } \\
1969, \text { June-July } \\
1970 \text {, June-July } \\
1971 \text { ) }\end{array}$ \\
\hline $\begin{array}{l}\text { Schechter } \\
(1986)^{20}\end{array}$ & $\begin{array}{l}\text { Greenland } \\
\text { (Greenlandic } \\
\text { Inuit) }\end{array}$ & 50000 (80\% Indigenous) & Alcohol rationing & $\begin{array}{l}\text { Rationing ordinance } \\
\text { passed by the } \\
\text { Greenland Council } \\
\text { following public } \\
\text { plebiscite }\end{array}$ & Alcohol sales; crime & $\begin{array}{l}\text { Alcohol sales or } \\
\text { consumption data }\end{array}$ & 6 years (1978-1984) \\
\hline $\begin{array}{l}\text { Gallaher et al } \\
(1992)^{27}\end{array}$ & $\begin{array}{l}\text { USA (Native } \\
\text { American) }\end{array}$ & $\begin{array}{l}123000 \text { (all residents of } \\
\text { New Mexico) }\end{array}$ & $\begin{array}{l}\text { Prohibition of sale, } \\
\text { importation or possession }\end{array}$ & $\begin{array}{l}\text { Tribally imposed } \\
\text { prohibition laws }\end{array}$ & Unintentional injury & $\begin{array}{l}\text { Cause-specific mortality } \\
\text { data; Hospital records or } \\
\text { medical examiner } \\
\text { reports; Traffic accident } \\
\text { report files (containing } \\
\text { location of Indigenous } \\
\text { pedestrian deaths) }\end{array}$ & $\begin{array}{l}10 \text { years ( January } 1 \\
1980 \text { to December } 31 \\
1989 \text { ) }\end{array}$ \\
\hline Lee $(1993)^{25}$ & $\begin{array}{l}\text { USA (Alaska } \\
\text { Native) }\end{array}$ & $\begin{array}{l}8 \text { Indigenous villages (of } \\
57 \text { in the region) }\end{array}$ & $\begin{array}{l}\text { Restrictions on liquor sold, } \\
\text { times of sale or mode of } \\
\text { sale; traditional forms of } \\
\text { control }\end{array}$ & Local option law & $\begin{array}{l}\text { Crime; Intentional } \\
\text { injury (self-harm, } \\
\text { attempted suicide or } \\
\text { suicide) }\end{array}$ & $\begin{array}{l}\text { Crime data for serious or } \\
\text { minor offences }\end{array}$ & 5 years $(1983-1987)$ \\
\hline $\begin{array}{l}\text { Chiu et al } \\
(1997)^{16}\end{array}$ & $\begin{array}{l}\text { USA (Alaska } \\
\text { Native) }\end{array}$ & 4000 (61\% Indigenous) & $\begin{array}{l}\text { Prohibition of sale, } \\
\text { importation or possession }\end{array}$ & Local option law & $\begin{array}{l}\text { Social or health service } \\
\text { usage }\end{array}$ & $\begin{array}{l}\text { Alcohol-related } \\
\text { outpatient visit records }\end{array}$ & $\begin{array}{l}33 \text { months } \\
\text { (November } 1993 \\
\text { through July 1996) }\end{array}$ \\
\hline $\begin{array}{l}\text { Landen et al } \\
(1997)^{24}\end{array}$ & $\begin{array}{l}\text { USA (Alaska } \\
\text { Native) }\end{array}$ & $\begin{array}{l}\text { Dry villages: } 63419 \\
\text { person-years }(93 \% \\
\text { Indigenous) } \\
\text { Wet villages: } \\
38867 \text { person-years } \\
\left(55 \% \text { Indigenous) }{ }^{*} \dagger\right.\end{array}$ & $\begin{array}{l}\text { Prohibition of sale, } \\
\text { importation or possession }\end{array}$ & Local option law & Unintentional injury & $\begin{array}{l}\text { Cause-specific mortality } \\
\text { data }\end{array}$ & 3 years (1990-1993) \\
\hline $\begin{array}{l}\text { Landen } \\
(1997)^{23}\end{array}$ & $\begin{array}{l}\text { USA (American } \\
\text { Indian) }\end{array}$ & $\begin{array}{l}\text { Wet reservations: } \\
(1)<5000 ;(2) 5000- \\
10000 ;(3)<5000(4) \\
5000-10000 \text { (5) 5000- } \\
10000 \\
\text { Dry reservations: } \\
(6 / 7) 10000-15000 \\
10000-15000 \text { (8) } 5000- \\
10000\end{array}$ & $\begin{array}{l}\text { Prohibition of sale, } \\
\text { importation or possession }\end{array}$ & $\begin{array}{l}\text { Tribally imposed } \\
\text { prohibition laws }\end{array}$ & $\begin{array}{l}\text { Alcohol-related } \\
\text { mortality }\end{array}$ & $\begin{array}{l}\text { American Indian } \\
\text { mortality data by county }\end{array}$ & $\begin{array}{l}11 \text { years }(1979- \\
1990)\end{array}$ \\
\hline
\end{tabular}

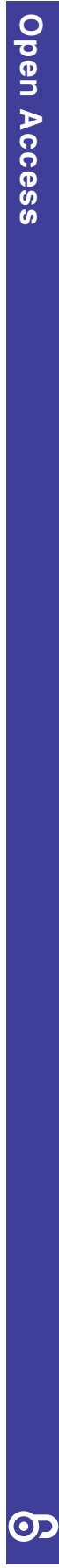

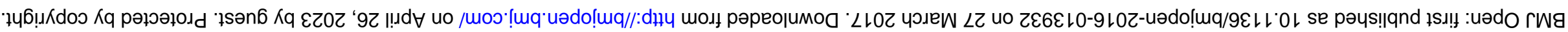




\begin{tabular}{|c|c|c|c|c|c|c|c|}
\hline $\begin{array}{l}\text { Author } \\
\text { (year) }\end{array}$ & $\begin{array}{l}\text { Country of } \\
\text { origin } \\
\text { (Indigenous } \\
\text { population) }\end{array}$ & Population size & $\begin{array}{l}\text { Category of alcohol } \\
\text { control }\end{array}$ & Legal instruments & $\begin{array}{l}\text { Health and social } \\
\text { outcomes reported }\end{array}$ & Data collected & $\begin{array}{l}\text { Time Horizon of } \\
\text { evaluation }\end{array}$ \\
\hline $\begin{array}{l}\text { Douglas } \\
(1998)^{17}\end{array}$ & $\begin{array}{l}\text { Australia } \\
\text { (Aboriginal and or } \\
\text { Torres Strait } \\
\text { Islander- } \\
\text { primarily Kija and } \\
\text { Djaru language } \\
\text { groups) }\end{array}$ & $\begin{array}{l}\text { 1200 with } 3000 \text { from } \\
\text { surrounding towns ( } 63 \% \\
\text { Indigenous) }\end{array}$ & $\begin{array}{l}\text { Restrictions on liquor sold, } \\
\text { times of sale or mode of } \\
\text { sale }\end{array}$ & $\begin{array}{l}\text { Regulation instituted } \\
\text { by state or territory } \\
\text { liquor licensing } \\
\text { authorities }\end{array}$ & $\begin{array}{l}\text { Crime; Social or health } \\
\text { service usage }\end{array}$ & $\begin{array}{l}\text { Alcohol sales or } \\
\text { consumption data }\end{array}$ & 3 years (1991-1994) \\
\hline $\begin{array}{l}\text { d'Abbs } \\
(1998)^{29}\end{array}$ & $\begin{array}{l}\text { Australia } \\
\text { (Aboriginal and } \\
\text { Torres Strait } \\
\text { Islander) }\end{array}$ & $\begin{array}{l}7 \text { Indigenous } \\
\text { communities (of total of } 8 \\
\text { with licensed clubs) }\end{array}$ & $\begin{array}{l}\text { Indigenous-controlled } \\
\text { liquor licensing }\end{array}$ & Not stated & Alcohol consumption & $\begin{array}{l}\text { Alcohol sales or } \\
\text { consumption data }\end{array}$ & 1 year (1994-1995) \\
\hline $\begin{array}{l}\text { Berman et al } \\
(2000)^{22}\end{array}$ & $\begin{array}{l}\text { USA (Alaska } \\
\text { Native) }\end{array}$ & $\begin{array}{l}29000 \text { ( } 26000 \text { in control } \\
\text { group) }\end{array}$ & $\begin{array}{l}\text { Indigenous-controlled } \\
\text { liquor licensing; } \\
\text { Prohibition of sale, } \\
\text { importation or possession }\end{array}$ & Local option law & Injury & $\begin{array}{l}\text { Legal determinations } \\
\text { classifying injury deaths } \\
\text { (data not available to } \\
\text { determine whether } \\
\text { alcohol-related) }\end{array}$ & $\begin{array}{l}13 \text { years }(1980- \\
1993)\end{array}$ \\
\hline $\begin{array}{l}\text { Gray et al } \\
(2000)^{15}\end{array}$ & $\begin{array}{l}\text { Australia } \\
\text { (Aboriginal and } \\
\text { Torres Strait } \\
\text { Islander) }\end{array}$ & $\begin{array}{l}\sim 2700 \text { (all residents of } \\
\text { Tennant Creek) }\end{array}$ & $\begin{array}{l}\text { Restrictions on liquor sold, } \\
\text { times of sale or mode of } \\
\text { sale }\end{array}$ & $\begin{array}{l}\text { Regulation instituted } \\
\text { by state or territory } \\
\text { liquor licensing } \\
\text { authorities }\end{array}$ & $\begin{array}{l}\text { Alcohol consumption; } \\
\text { hospital admissions; } \\
\text { admissions to local } \\
\text { women's refuge and } \\
\text { sober up shelter; } \\
\text { crime; }\end{array}$ & $\begin{array}{l}\text { Alcohol sales data, } \\
\text { health and social service } \\
\text { admissions data; local } \\
\text { police data }\end{array}$ & 4 years $(1994-1998)$ \\
\hline Ellis $(2003)^{28}$ & $\begin{array}{l}\text { USA (American } \\
\text { Indian) }\end{array}$ & $\begin{array}{l}\text { McKinley County: } 43000 \\
\text { Indigenous } \\
\text { Fremont: } 7000 \\
\text { Indigenous }\end{array}$ & $\begin{array}{l}\text { Restrictions on liquor sold, } \\
\text { times of sale or mode of } \\
\text { sale; local excise tax; } \\
\text { enhanced law } \\
\text { enforcement }\end{array}$ & Local option law & $\begin{array}{l}\text { Crime; Mortality (motor } \\
\text { vehicle accident } \\
\text { mortality, homicide, } \\
\text { suicide and } \\
\text { alcohol-induced } \\
\text { causes); Motor vehicle } \\
\text { accidents }\end{array}$ & $\begin{array}{l}\text { Alcohol sales or } \\
\text { consumption data; } \\
\text { adolescent substance } \\
\text { use data; Hospital } \\
\text { records or medical } \\
\text { examiner reports; Traffic } \\
\text { accident report files; } \\
\text { crime data for serious or } \\
\text { minor offences }\end{array}$ & $\begin{array}{l}21 \text { years (1974- } \\
1995) \text { for annual } \\
\text { mortality rates for } \\
\text { selected substance } \\
\text { abuse-related } \\
\text { causes; } 1 \text { year } \\
\text { (1989-96) for traffic } \\
\text { crash rates. }\end{array}$ \\
\hline $\begin{array}{l}\text { Wood and } \\
\text { Gruenewald } \\
(2006)^{8}\end{array}$ & $\begin{array}{l}\text { USA (Alaska } \\
\text { Native) }\end{array}$ & $\begin{array}{l}\text { Dry villages: } 165191 \\
\text { person-years (108 } 906 \\
\text { with and } 56285 \text { without } \\
\text { local police presence) } \\
\text { Wet villages: } 67906 \\
\text { person-years ( } 45655 \\
\text { person-years with and } \\
22251 \text { person-years } \\
\text { without local police } \\
\text { presence) }{ }^{*}+\end{array}$ & $\begin{array}{l}\text { Prohibition of sale, } \\
\text { importation or possession }\end{array}$ & Local option law & $\begin{array}{l}\text { Motor vehicle } \\
\text { accidents; Intentional } \\
\text { injury (self-harm, } \\
\text { attempted suicide or } \\
\text { suicide); Intentional } \\
\text { injury (self-harm, } \\
\text { attempted suicide or } \\
\text { suicide) }\end{array}$ & $\begin{array}{l}\text { Serious injury data } \\
\text { obtained from state } \\
\text { trauma registries; data } \\
\text { pertaining to police } \\
\text { presence (number of } \\
\text { months that a village had } \\
\text { a police service used as } \\
\text { an indicator of police } \\
\text { presence) }\end{array}$ & $\begin{array}{l}10 \text { years }(1991- \\
2000)\end{array}$ \\
\hline
\end{tabular}




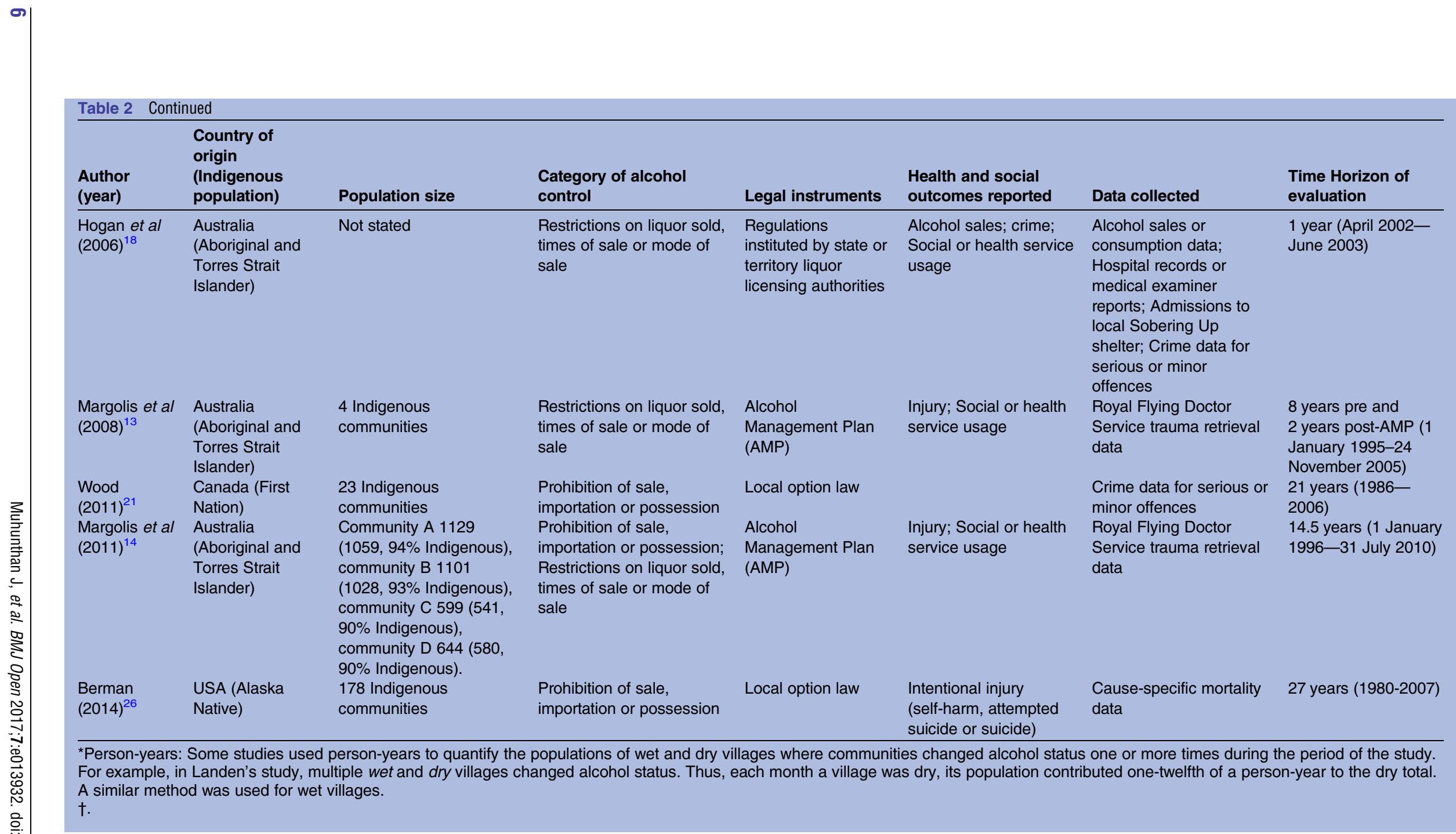


facilitated community-led controls included prohibition and restriction controls that were facilitated by local option laws that allowed communities to vote on their desired form of alcohol control (eg, that alcohol could be bought and sold, imported, sold and imported or that possession was to be prohibited) through legally held referendums. ${ }^{22} \mathrm{~A}$ third model involved 'community coalitions' backed by government intervention. In an Australian study in the Kimberley region, this involved the Alcohol Action Advisory Committee consisting of police, health, Aboriginal Legal Services and faith-based organisations as well as individual members of the community who together lobbied the state Director of Liquor Licensing to impose alcohol restrictions. ${ }^{17} \mathrm{~A}$ fourth model of governance involved government initiated community partnerships such as Queensland Australia's Meeting Challenges, Making Choices Committee. The Committee involved community justice groups and Indigenous Elders tasked with developing alcohol management plans for their communities in partnership with government agencies. ${ }^{13} 14$

\section{Use of evidence in informing controls}

The extent to which research evidence or population data was used by communities to inform the development and implementation of controls is unclear as most studies $(n=17)$ did not report this. One study reported that research evidence pertaining to the severity of local burden and conditions was available to tribal leaders and the public. ${ }^{28}$ In that study, research evidence and population health data, in combination with the local knowledge of tribal leaders, helped to inform decision makers about the various dimensions of the substance abuse problem, provide indicators for the ongoing monitoring of progress and safeguard against unintended impacts on vulnerable sectors of the community through the development of programmes (eg, an alcohol crisis centre, alcohol server training and KICK-IT, an adolescent programme targeting at-risk youth).

\section{Enforcement of alcohol controls}

One study investigated the impact of the brief legalisation of alcohol in a large American Indian tribe on the Great Plains where the possession and use of alcohol had never been legal. That study estimated that arrests for intoxication declined immediately after legalisation. ${ }^{19}$ The findings suggested that the enforcement of prohibition controls did not necessarily reduce incidences of harmful alcohol use. For example, authors hypothesised that drinkers were less likely to rapidly consume alcohol in attempts to circumvent prohibition controls when alcohol was legal. Another study from the US, reported that despite prohibition on the sale and importation of alcohol, 117 convictions for bootlegging were enforced by the Alaska Alcoholic Beverage Control Board over the 3-year evaluation. ${ }^{24}$

Sixteen studies did not report quantitative data regarding the legal enforcement of the alcohol controls.
However, the authors noted several challenges, many specific to particular categories of control.

\section{Alcohol rationing}

With regards to alcohol rationing, alcohol coupons were legally non-transferable but the proper legal use of the coupons was seldom enforced. Identification was not requested and the point sheets were not printed with a marker of personal identification. ${ }^{20}$

\section{Prohibition and restriction controls}

With regards to the prohibition category, 'dry' communities that bordered 'wet' communities often found a persisting problem in the movement of heavy drinkers in 'dry' communities to other towns where alcohol was legally available. ${ }^{19} 27$ In New Mexico, this resulted in limited options for intoxicated persons to travel home safely and deaths due to hypothermia or pedestrian accidents resulting from travelling the large distances between towns. $^{27}$

In studies that evaluated interventions in the prohibition or restriction categories, providing adequate police services in rural areas was problematic. ${ }^{8}$ Challenges included difficulties imposed by extreme weather and an absence of roads connecting communities to major towns. In one study, this precluded the deployment of trained state-certified police officers to the most isolated Alaska Native villages. Only a few communities had their own local departments that employed fully certified police officers. Other villages were served by noncertified para-professional Village Public Safety Officers. However, many villages went months without the presence of an officer due to extremely high rates of attrition of officers. Some villages had no local police presence and were instead served by state troopers on an as-needed basis by air or river. ${ }^{8}$

The presence of illegal smuggling of alcohol into communities, and then unlicensed sales to drinkers presented a challenge to enforcement for other communities. In one study, authors cited anecdotal reports and unpublished consultation data pointing to rising rates of sly grogging in some communities in Cape York, Queensland. ${ }^{14}$ However, one study reported that stronger enforcement measures had brought about increased efficiency. Code enforcement had become increasingly diligent and in combination with the enforcement of other liquor laws, had the effect of reducing the frequency of inappropriate alcohol sales. The measures also led to increased community cohesion and engagement with alcohol sellers. When hours for drive-up alcohol sales were restricted, some alcohol sellers voluntarily closed their drive-up windows. ${ }^{28}$

\section{Traditional forms of control}

With regard to traditional forms of control, a significant issue was that the village social structure did not support a village member assuming a formal, external, authoritarian role. Having to interfere with personal 
relationships or arrest one's friends and relatives was not compatible with village life. ${ }^{25}$

\section{Effectiveness of interventions}

In 11 of the 18 studies reviewed, the Indigenous-led alcohol controls employed were effective in achieving improvements in one or more health outcomes (eg, reductions in disease, injury or crime) (table 3). ${ }^{8}$ 13-17 20-22 2428 Interventions were classified as effective if the controls were associated with improvements within the same population or in comparison with other populations, except where authors deemed the results inconclusive due to methodological or reporting biases.

Seven of these studies involved the evaluation of one category of alcohol control. ${ }^{8} 131617202124$ The remaining four studies involved evaluations of multiple categories of alcohol control. ${ }^{14} 152228$ Prohibition of alcohol possession, sale or importation was the most frequently implemented form of alcohol control among those that were effective $(\mathrm{n}=6) .{ }^{8} 1416212224$

Five studies reported less crime in the communities studied (either in comparison to before the controls were implemented, or in comparison to other populations without similar controls). ${ }^{8} 17202128$ Three studies reported fewer injury deaths. ${ }^{22} 24 \quad 28$ Four studies reported fewer injuries in the communities studied. ${ }^{8} 131417$ One reported that annual per capita consumption of pure alcohol declined, as well as hospital admissions for acute alcohol-related conditions. ${ }^{15}$

Some alcohol controls were effective in achieving only some of the health outcome measures included in the evaluations. ${ }^{1722}$ In a US study of communities that went 'dry', by prohibiting the sale, importation and possession of alcohol, they achieved reductions in homicides but there was no effect on rates of suicide. Communities that became 'damp' achieved reductions in suicides, but there was no effect on homicides. ${ }^{22}$ In an Australian study, a package of interventions implemented in a single community including reduced trading hours for take-away outlets and restrictions on the type of alcohol sold at specific times of the day, achieved reductions in criminal charges imposed by the Halls Creek Police Station. Reductions were also achieved in aeromedical retrieval evacuations resulting from serious injury requiring hospital treatment and as such, could not be managed within the study communities. However, despite fluctuations in the data for domestic violence presentations to Halls Creek District Hospital, there was no discernible or statistically significant evidence of an increasing or decreasing trend in hospitalisations over a 2-year evaluation period. ${ }^{17}$ Controls also had unintended consequences. In Tennant Creek in Australia, despite overall reductions in per capita consumption, restrictions were circumvented with a shift to fortified wine purchases which remained accessible when sold in containers less than or equal to $1125 \mathrm{~mL}$. In addition, unlawful entries to dwellings significantly increased following the imposition of alcohol restrictions. ${ }^{15}$

In six studies, alcohol controls were ineffective (table 3)..$^{18} 1923262729$ In one study in New Mexico, US, there had been an increase in hypothermia and pedestrian deaths in response to restrictions that deemed alcohol possession and sale to be illegal. ${ }^{27}$ In another US study involving 178 Alaska Native communities, the prohibition on importation was shown to be ineffective in preventing suicide, the primary outcome of the study. This finding raised questions about whether alcohol was the causal factor in risk of suicide or a comorbid response to depression or other mental health problems. ${ }^{26}$ One US study found no significant differences in alcohol-related mortality between reservations where alcohol possession and use was prohibited and those where it was legal. ${ }^{23}$ In another US study, the short-lived (2-month) legalisation of alcohol possession and consumption saw a decline in arrests for driving while intoxicated. ${ }^{19}$ Arrests significantly increased following a return to prohibition. ${ }^{9}$

In the Northern Territory in Australia, Aboriginalcontrolled licensed clubs failed to lower persistently high consumption levels. Aboriginal-controlled licensed clubs, a term often used interchangeably with Aboriginal Social Clubs and wet canteens are specific community venues that encourage responsible drinking patterns (eg, through day caps, restrictions on hours of sale or bans on problem-drinkers) and reinforce community standards. In communities with these clubs, per capita consumption remained $183 \%$ higher than the territory average in males and $76 \%$ higher in females. ${ }^{29}$ Another Australian study within the same territory found that implementation of a suite of measures including restrictions on time of sale in take-away outlets, the removal of liquor in containers $>2 \mathrm{~L}$ and the provision of only light beer in bars before noon was not associated with a significant reduction in quarterly wholesale sales of pure alcohol over the 12-month trial period. Rather, drinkers shifted from one product to another product of equal price and purchased the same amount of pure alcohol. There was a shift in consumption from cask wine to $2 \mathrm{~L}$ cask port which was priced at 28 cents (AUD) per $10 \mathrm{~mL}$, the same price as alcohol in the 4 and $5 \mathrm{~L}$ casks that became unavailable under the trial restrictions. ${ }^{18}$

In a study of Alaska Natives, the results were inconclusive. ${ }^{25}$ The data showed that villages that had maintained traditional forms of social control had less crime (including felonies and misdemeanours, with the exception of liquor violations as well as drunk in public and protective custody incidents). However, the authors reasoned that this may be linked to reporting mechanisms - the abolition of VPSO positions, avoiding contact with state troopers, relying on traditional mechanisms with no formal records of crime or choosing to ignore certain behaviours. Another possibility that was highlighted is that such communities are more culturally cohesive as they have retained traditional (Yup'ik) values 
Table 3 Effect of legal interventions to control alcohol on health and social outcomes

\begin{tabular}{|c|c|}
\hline Author (year) & Main results \\
\hline May $(1975)^{19}$ & $\begin{array}{l}\text { Arrests declined for the 2-month period of alcohol legalisation by } 30 \% \text { (182 in June-July of } 1969 \text { to } \\
126 \text { in June-July of 1970). } \\
\text { Following the repeal, arrests rose by over } 30 \% \text { to } 189 \text { in June-July of } 197.1 \\
\text { Data pertaining to individual arrests was unavailable. However, at an aggregate level in } 1969 \text { and } \\
1970,88.7 \% \text { of Native American arrests within and bordering the reservations were for alcohol } \\
\text { intoxication and driving while intoxicated. }\end{array}$ \\
\hline Schechter $(1986)^{20}$ & $\begin{array}{l}\text { Overall importation and consumption declined significantly. } \\
\text { Number of drinks imported fell from } 47 \text { million in } 1978 \text { to } 35.2 \text { million in 1979, } 30.5 \text { million in } 1980 \\
\text { and } 36 \text { million in } 1981 . \\
\text { Litres of pure alcohol consumed dropped from } 513627 \text { in } 1978 \text { to } 406856 \text { in } 1979,346384 \text { in } 1980 \\
\text { and } 43606 \text { in } 1981 . \\
\text { National crime rate dropped markedly particularly violent crimes (murder, attempted murder and } \\
\text { assault). } \\
\text { After the repeal of alcohol rationing, consumption and importation rose by } 60 \% \text { and incidences of } \\
\text { crime increased significantly. }\end{array}$ \\
\hline $\begin{array}{l}\text { Gallaher et al } \\
(1992)^{27}\end{array}$ & $\begin{array}{l}\text { Over } 50 \% \text { excess mortality from all unintentional injuries among Native Americans resulted from } \\
\text { hypothermia and pedestrian-motor vehicle crashes. } \\
\text { New Mexico Native Americans nearly eight times more likely to die of hypothermia compared with } \\
\text { other New Mexico residents. } \\
\text { At death, } 90 \% \text { of those Native Americans tested were highly intoxicated (median blood alcohol } \\
\text { concentrations of } 0.24 \text { and } 0.18 \mathrm{mg} / \mathrm{dL} \text { for pedestrian and hypothermia deaths, respectively). } \\
\text { Most deaths occurred at off-reservation sites in border towns and on roads leading back to the } \\
\text { reservation. }\end{array}$ \\
\hline Lee $(1993)^{25}$ & $\begin{array}{l}\text { Of } 9882 \text { reported incidents of crime overall, Nation villages (employing traditional forms of control) } \\
\text { reported } 34.5 \% \text { of the total, non-Nation villages (employing local option controls) reported } 65.5 \% \text { of } \\
\text { the total. } \\
\text { Rates for felonies and misdemeanors were lower in Nation villages, with the exception of liquor } \\
\text { violations and drunk in public and protective custody incidents. } \\
\text { In non-Nation villages, incidence of strongarm rape were } 6.9 \text { times higher, non-aggravated assault } \\
\text { were } 3.8 \text { times higher, burglary } 2.9 \text { times higher and sexual assault } 5 \text { times higher. } \\
\text { Nation villages reported more protective custody and drunk-in-public incidents than non-Nation } \\
\text { villages, yet serious reported crime were lower. }\end{array}$ \\
\hline Chiu et al (1997) & $\begin{array}{l}\text { Substantial decrease in the number of alcohol-related outpatient visits when the ban on possession } \\
\text { and importation was imposed compared with baseline. } \\
\text { When the ban was lifted, outpatient visits increased; when the ban was reimposed, the number of } \\
\text { outpatient visits again decreased. } \\
\text { Interrupted time-series analysis confirmed that the alcohol ban, its lifting and its reimposition had a } \\
\text { statistically significant and negative effect on the number of alcohol-related outpatient visits }(p<0.05) \text {. } \\
\text { A significantly higher number of visits were made during the two non-ban periods (November } \\
\text { 1993-October 1994) and November } 1995-\text { February 1996) compared with the two ban periods }(p<0.05) \text {. }\end{array}$ \\
\hline $\begin{array}{l}\text { Landen et al } \\
(1997)^{24}\end{array}$ & $\begin{array}{l}\text { Of } 302 \text { injury deaths, blood alcohol concentrations (BACs) were available for } 200 \text { deaths }(66.2 \%) \text {. Of } \\
\text { these, } 130(65.0 \%) \text { had a BAC greater than or equal to } 17 \mathrm{mmol} / \mathrm{L} \text { (greater than or equal to } 80 \mathrm{mg} / \\
\mathrm{dL} \text { ) and were therefore considered alcohol-related. } \\
\text { Total injury mortality rate was greater among Alaska Natives from wet villages (rate ratio (RR), 1.6; } \\
95 \% \mathrm{Cl} 1.3 \text { to } 1.2) \text {. This difference was not present for non-natives (RR, } 1.1 ; 95 \% \mathrm{Cl} 0.3 \text { to } 3.8) \text {. } \\
\text { For Alaska Natives, the alcohol-related injury mortality was greater among residents of wet villages } \\
\text { (RR, } 2.7 ; 95 \% \mathrm{Cl} 1.9 \text { to } 3.8 \text { ) than among residents of dry villages. The strength of this association } \\
\text { was greatest for deaths due to motor vehicle injury, homicide and hypothermia. }\end{array}$ \\
\hline Landen $(1997)^{23}$ & $\begin{array}{l}\text { No significant differences across reservations with prohibition controls and those where alcohol was } \\
\text { legal. The average age-adjusted mortality rate found that the mortality rate was higher }(n=158) \text { than } \\
\text { prohibition }(n=138) \text { reservations. }\end{array}$ \\
\hline Douglas (1998) ${ }^{17}$ & $\begin{array}{l}\text { Decrease in alcohol consumption observed for each of the } 2 \text { years following the intervention. } \\
\text { Overall, incidence of crime declined. } \\
\text { decreased relative to the equivalent quarterly period prior to the intervention. Short-term fluctuations } \\
\text { were observed, particularly with domestic violence, where presentations (of lesser severity) became } \\
\text { more request during several quarters. }\end{array}$ \\
\hline
\end{tabular}


Table 3 Continued

\begin{tabular}{|c|c|}
\hline Author (year) & Main results \\
\hline D'Abbs (1998) $^{29}$ & $\begin{array}{l}\text { Mean consumption levels in standard drink terms, the corresponding equivalents were } 5.8 \text { standard } \\
\text { drinks per day for female drinkers and } 9.3 \text { for male drinkers. } \\
\text { Among both male and female drinkers, the overall mean consumption levels were } \sim 50 \% \text { above the } \\
\text { level designated as harmful. } \\
\text { In one community, mean consumption lay in the responsible range and the other in the hazardous } \\
\text { range. In all others, male and females were above the harmful level. } \\
\text { Total beer sales in the seven clubs }(1994-1995) \text { amounted to } 882259 \mathrm{~L} \text {. Assuming a retail price of } \\
\$ 3.50 \text { per } 375 \mathrm{~mL} \text { can of full-strength beer and } \$ 3.00 \text { per can of light beer, the total retail turnover } \\
\text { would amounted to } ~ \$ 8.1 \text { million. }\end{array}$ \\
\hline $\begin{array}{l}\text { Berman et al } \\
(2000)^{22}\end{array}$ & $\begin{array}{l}\text { Injury deaths generally lower during periods when alcohol sales, importation or possession were } \\
\text { restricted than when no restrictions were in place (wet). } \\
\text { More restrictive controls (dry) significantly reduced homicides but had no effect on suicide rates; less } \\
\text { restrictive control options (damp) reduced suicides but had no effect on homicide rates. } \\
\text { Accident and homicide death rates fell, on average, by } 74 \text { and } 66 \text { per } 100000 \text {, respectively, for the } \\
89 \text { communities that banned sale and importation or possession. Sixty-one small communities that } \\
\text { did not change control status under the law showed no significant changes over time in accident or } \\
\text { homicide death rates. } \\
\text { The decline in overall injury death rates was much greater in communities with less restrictive } \\
\text { options (127 compared to } 48 \text { per } 100 \text { 000). However, death rates were higher in these communities } \\
\text { while they were wet, with the discrepancy statistically significant for suicides. }\end{array}$ \\
\hline Gray et al (2000) ${ }^{15}$ & $\begin{array}{l}\text { Annual per capita consumption declined by } 19.4 \% \text { in the } 2 \text { years following the introduction of alcohol } \\
\text { restrictions. } \\
\text { Hospital admissions for acute alcohol-related conditions declined. } \\
\text { Restrictions were circumvented by a shift to fortified wine purchases. Fortified wine purchases } \\
\text { increased by } 570 \%(573 \mathrm{~L}) \text { offsetting } 14 \% \text { of the mean quarterly decline of } 4173 \mathrm{~L} \text { of cask wine } \\
\text { immediately following the restrictions. } \\
\text { Purchases at Aboriginal-controlled licensed clubs (also not covered by the restrictions) increased by } \\
55.7 \% \text { from } 2801 \mathrm{~L} \text { to } 1799 \mathrm{~L} \text { of pure alcohol and offsetting } 20 \% \text { of the mean quarterly decline of } \\
3002 \mathrm{~L} \text {. }\end{array}$ \\
\hline Ellis $(2003)^{28}$ & $\begin{array}{l}\text { Following the introduction of restrictions on liquor sold, times of sale or mode of sale, a local excise } \\
\text { tax and enhanced law enforcement measures, from } 1974 \text { to } 1995 \text {, McKinley County's (MC) motor } \\
\text { vehicle accident mortality rate declined by } 60 \% \text { and was matched by similar declines in mortality } \\
\text { from homicide (58\%), suicide (59\%), alcohol-induced causes (30\%) and drug-induced causes (50\%). } \\
\text { From } 1989 \text { to } 1995 \text {, alcohol-related arrests declined } 42 \% \text { in Gallup, and protective custody } \\
\text { detentions were cut in half. Between } 1982 \text { and } 1995 \text {, traffic crashes had declined } 32 \% \text { in MC. All } \\
\text { declines experienced in MC exceeded similar trends for New Mexico and the nation. }\end{array}$ \\
\hline Wood $(2006)^{8}$ & $\begin{array}{l}\text { Villages prohibiting alcohol had lower age-adjusted rates of serious injury resulting from assault, } \\
\text { motor vehicle collisions. Dry villages with a local police presence had a lower age-adjusted rate of } \\
\text { serious injury caused by assault. } \\
\text { Local prohibition was associated with lower rates of assault injuries. } \\
\text { Local police presence was associated with lower rates of assault injuries. Contrary to expectations, } \\
\text { there was no difference in the age-adjusted rate of injury attributed to self-harm for wet vs dry } \\
\text { isolated Alaska Native villages. Rates of serious injury caused by assault were } 36 \% \text { higher in } \\
\text { villages during periods of police absence than when police were present. }\end{array}$ \\
\hline $\begin{array}{l}\text { Hogan et al } \\
(2006)^{18}\end{array}$ & $\begin{array}{l}\text { Over } 12 \text { months the reduction in trading hours was accompanied by decreased levels of } \\
\text { alcohol-related harm. However, the regulation of container size was undermined by a shift to cheap } \\
\text { cask port with sales of this product increasing by } 1000 \% \text {. } \\
\text { A one-third reduction was observed in instances of drunkenness and breaches of the } 2 \mathrm{~km} \text { law, as } \\
\text { were Protective Custodies. } \\
\text { Ambulance services received } 25 \% \text { less alcohol-related call-outs and selected presentation to the } \\
\text { emergency department of Alice Springs were reduced by } 19 \% \text {. } \\
\text { Alcohol-related assaults were } 13 \% \text { lower. There was a nearly } 20 \% \text { increase in alcohol-related } \\
\text { offences, especially criminal damage and disturbances and indications of more acute conditions } \\
\text { being admitted to Alice Springs Hospital. However, the author's reanalysis of these findings found } \\
\text { that the evaluators did not provide sufficient data to ascertain whether these were significant } \\
\text { reductions of chance phenomena. }\end{array}$ \\
\hline $\begin{array}{l}\text { Margolis et al } \\
(2008)^{13}\end{array}$ & 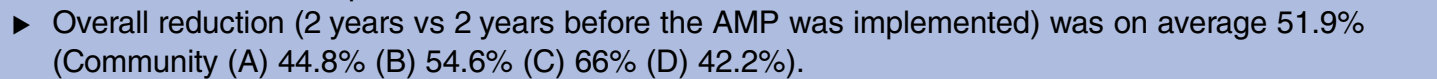 \\
\hline
\end{tabular}


Table 3 Continued

\begin{tabular}{|c|c|}
\hline Author (year) & Main results \\
\hline & $\begin{array}{l}\text { Retrieval rates for all other causes did not reveal any statistically significant change. Serious injury } \\
\text { resulted in } 798 \text { retrievals during the observation period. There was a significant }(p=0.021) \text { decrease } \\
\text { in injury after the introduction of AMP. }\end{array}$ \\
\hline \multirow[t]{3}{*}{ Wood $(2011)^{21}$} & $\begin{array}{l}\text { Wet communities in Nunavut recorded rates of violent crime that were higher than dry communities. } \\
\text { Relative to dry communities, wet communities' overall sexual assault rate was } 1.48(95 \% \mathrm{Cl} 1.38 \text { to } \\
\text { 1.60) times higher, the serious assault rate was } 2.10 \text { ( } 95 \% \mathrm{Cl} 1.88 \text { to } 2.35) \text { times higher and the } \\
\text { homicide rate was } 2.88(95 \% \mathrm{Cl} 1.18 \text { to } 8.84) \text { times higher. }\end{array}$ \\
\hline & $\begin{array}{l}\text { Dry communities were safer than wet communities but still reported rates of violence that were } \\
\text { higher than national rates, including a serious assault rate that was double the national rate ( } 3.25 \text { per } \\
1000 \text { vs } 1.44 \text { per } 1000) \text { and a sexual assault rate that was at least seven times as high as the } \\
\text { national rate }(7.58 \text { per } 1000 \text { vs } 0.88 \text { per } 1000) \text {. }\end{array}$ \\
\hline & $\begin{array}{l}\text { Homicide, the rarest violent offence, was relatively more frequent in wet communities than in dry } \\
\text { communities ( } \mathrm{RR}=2.88 ; 95 \% \mathrm{Cl} 1.18 \text { to } 8.84) \text {. }\end{array}$ \\
\hline $\begin{array}{l}\text { Margolis et al } \\
(2011)^{14}\end{array}$ & $\begin{array}{l}\text { After alcohol restrictions were introduced in } 2002-2003 \text {, retrievals for serious injury dropped initially, } \\
\text { then increased in the } 2 \text { years before further restrictions in } 2008 \text { (average increase, } 2.34 \text { per } 1000 \text { per } \\
\text { year). This trend reversed in the } 2 \text { years after the } 2008 \text { restrictions (average decrease } 7.97 \text { per } 1000 \\
\text { per year). }\end{array}$ \\
\hline & $\begin{array}{l}\text { There was a statistically significant decreasing time trend in serious-injury retrieval rates in each of } \\
\text { the four communities for the period } 2 \text { years before the } 2002-2003 \text { restrictions, } 2 \text { years before the } \\
2008 \text { restrictions and the final } 2 \text { years of observations }(2009-2010)(p<0.001 \text { for all four communities } \\
\text { combined). }\end{array}$ \\
\hline & $\begin{array}{l}\text { Overall, serious injury retrieval rates dropped from } 30 \text { per } 1000 \text { in } 2008 \text { to } 14 \text { per } 1000 \text { in } 2010 \text {, and } \\
\text { the proportions of serious-injury retrievals decreased significantly for all four communities. }\end{array}$ \\
\hline \multirow[t]{6}{*}{ Berman $(2014)^{26}$} & $\begin{array}{l}\text { Suicide rates were higher in communities prohibiting alcohol importation under state law, but the } \\
\text { effect was not significant after controlling for other community characteristics. } \\
\text { More remote communities, those with fewer non-Natives and those with evidence of cultural divides } \\
\text { had higher suicide risks. }\end{array}$ \\
\hline & $\begin{array}{l}\text { Communities with higher incomes, more married couples and traditional elders had lower risks. } \\
\text { There was a strong association of community characteristics with the choice of alcohol status, } \\
\text { consistent with the hypothesis that it is endogenous. }\end{array}$ \\
\hline & $\begin{array}{l}\text { Communities choosing alcohol control by referendum were generally larger, with a higher percentage } \\
\text { of Alaska Native residents and more remote. }\end{array}$ \\
\hline & Communities with lower median incomes were more likely to choose prohibition. \\
\hline & $\begin{array}{l}\text { Young men's suicide risks were significantly higher }(p<0.01) \text { when alcohol was prohibited under the } \\
\text { state local option law. }\end{array}$ \\
\hline & $\begin{array}{l}\text { The association between adoption of any local alcohol control option and suicide was even stronger } \\
(p=0.01) \text {. However, communities using federal Indian law to ban alcohol had significantly lower } \\
\text { suicide risks }(p<0.5) \text {. }\end{array}$ \\
\hline
\end{tabular}

to a greater extent than communities with 'Western mechanisms' of social control developed by state and federal governments and operationalised by authorities (eg, 'judges, magistrates, district courts and marshals') external to Indigenous social and cultural systems. ${ }^{28}$

\section{DISCUSSION}

This review found 18 quantitative evaluations of Indigenous-led alcohol controls. The controls were implemented in rural and remote populations in highincome countries. Prohibition on the sale, importation or possession of alcohol was the predominant category of control. Eleven of the 18 studies found one or more alcohol controls (predominantly prohibition) to be effective in improving a broad range of health and social outcomes including reduced rates of hospitalisations, injury and crime.
The findings of this review add to qualitative research that has explored the widespread and under-recognised agency of Indigenous communities to engage in effective health governance. ${ }^{30} 31$ The studies reveal a widespread preference for strong, legal responses to public health problems such as harmful alcohol use which confirm findings of qualitative work exploring community views regarding Indigenous-led alcohol controls. ${ }^{15} 32$ In addition, they suggest that many such policy models characterised by community representation and leadership in the development and implementation of alcohol controls are effective in improving health outcomes and deserve serious consideration by governments who can facilitate opportunities for Indigenous populations globally to actively participate in the advocacy, design and implementation of public health law.

Nevertheless, the results reveal the complexity involved in implementing Indigenous-led alcohol controls such 
that populations benefit (in terms of health and social outcomes and other social goods including community engagement and capacity building) and vulnerable members of the community are not further disadvantaged. Many of the studies reviewed reported unintended impacts on vulnerable members of communities including those experiencing substance addiction, unemployment, poverty, women and children and other at-risk populations. This was particularly significant for communities that were not geographically isolated from communities where alcohol was legally available. The availability of alcohol in other regions carried the potential to undermine controls in neighbouring 'dry' or 'damp' communities by facilitating heavy drinking in neighbouring areas without alcohol restrictions or the illegal importation of alcohol into 'dry' areas. For example, the introduction of prohibition, the strongest form of alcohol control carried health risks to individuals experiencing substance abuse and travelling long distances to neighbouring areas to obtain alcohol. Health risks included hypothermia due to excessively cold weather conditions, hunger and thirst and pedestrian deaths due to being struck by a vehicle driven by an intoxicated driver or exposure to risk as an intoxicated pedestrian. ${ }^{27}$ This information problem is pervasive in under-resourced and marginalised communities. ${ }^{33}$ However, the experience of McKinley County in the US, where sizable declines $(60 \%)$ in the rate of motor vehicle accident mortality and (40\%) in alcoholrelated arrests were achieved, may suggest that communities could benefit from being able to access and use research evidence and public health surveillance systems to inform local alcohol policy. ${ }^{28}$

Another significant challenge faced by communities was maintaining the sustainability of the controls, which in many cases were repealed and reinstated on multiple occasions. This occurred due to demographic change (eg, a higher proportion of non-Indigenous voters, who were less likely to support alcohol restrictions), local business and economic interests, unpopularity of the control and inadequate resourcing to combat unlicensed alcohol supply (bootlegging), unsafe home brewing and crime (eg, theft) committed with the intent of obtaining possession of alcohol. ${ }^{172022} 2427$ Prohibition controls that were implemented through local elections in the US and Canada could be repealed easily by local referendum and as such, many communities changed their alcohol status from year to year, highlighting the challenges of sustainability. ${ }^{1621}$ An additional challenge to the sustainability of controls is their enforcement. Few studies reported data (eg, arrests, imposition of penalties) on the extent to which controls were enforced. Such measures often do not reveal the true extent of compliance. However, to the extent that it is accessible, the reporting of these data could work to better inform and prepare communities as alcohol control models evolve and adapt to community need.

The responsibility of governments to protect the health of populations, particularly that of marginalised populations is almost universally recognised. ${ }^{34}{ }^{35}$ Further, national and subnational governments are considerably better resourced than Indigenous communities to meet this aim and as such, hold a unique position to contribute in the key areas highlighted in this review. ${ }^{34} 35$ The findings suggest that a first step could be taken in remedying the information problem by providing access to public health evidence and population data at the outset of the consultation and design process. This could enable a more targeted, informed and effective approach, help to identify potential unintended impacts on vulnerable individuals who may be disproportionately affected and identify measurable indicators for the monitoring and evaluation of the control. In addition, governments could provide support to ensure local decision makers have access to a context-specific menu of available legal avenues that communities can consider for potential effectiveness, acceptability and equity. Specifically, this could involve legal information pertaining to the availability of alcohol within the communities and in surrounding populations, legal status of the control, enforcement measures, the scope of the control, models for immediate and stepwise implementation and consideration of time horizons (eg, trial periods or sunset provisions). In addition, this could include the provision of case studies and evaluations of controls in other communities.

A key strength of this study is its comprehensiveness. No limitations were placed on the basis of language, study type, type of health or social outcome, measure of effectiveness or Indigenous population. Further, we included traditional forms of control that did not involve government intervention. One limitation is that we focused exclusively on the peer reviewed literature as it there are no comprehensive global holdings of the grey literature in this area.

\section{CONCLUSIONS}

Public health law can be a powerful prevention tool capable of alleviating the devastating effects of alcohol and alcohol-related harms, particularly where strengthened by community based and culturally sensitive enforcement mechanisms. Advocates and Indigenous health scholars have underscored the importance of Indigenous peoples retaining a place at the forefront of decision-making in a manner that is reflective of Indigenous rights including, but not exclusive to those enshrined in the UN Declaration on the Rights of Indigenous Peoples and distinct from the almost universal history of paternalistic alcohol control. ${ }^{56}$ The findings of this review indicate that community-led alcohol controls characterised by their development and/or implementation by Indigenous communities globally have been shown to be effective in improving health and social outcomes.

\section{Twitter Follow JANANI MUHUNTHAN @JanChildRights}

Contributors JM wrote the first draft and led the writing process. JM and BA independently conducted the systematic review with any uncertainties about 
inclusion or exclusion of empirical studies resolved in discussion with SJ and $\mathrm{MLH}$. All authors contributed to the conceptualisation and design of the paper. All authors contributed to the refinement of the manuscript.

Funding This research was supported by a Doctoral Scholarship (held by JM) from The Australian Prevention Partnership Centre, funded by NHMRC, the Australian Government Department of Health, NSW Ministry of Health, ACT Health and the HCF Research Foundation. SJ was in receipt of a NHMRC Senior Research Fellowship. MH was in receipt of a National Heart Foundation Future Leader Fellowship (100034).

Competing interests None declared.

Provenance and peer review Not commissioned; externally peer reviewed.

Data sharing statement No additional data are available.

Open Access This is an Open Access article distributed in accordance with the Creative Commons Attribution Non Commercial (CC BY-NC 4.0) license, which permits others to distribute, remix, adapt, build upon this work noncommercially, and license their derivative works on different terms, provided the original work is properly cited and the use is non-commercial. See: http:// creativecommons.org/licenses/by-nc/4.0/

\section{REFERENCES}

1. Brady M. Ethnography and understandings of Aboriginal drinking. J Drug Issues 1992;22:699-712.

2. Gray D, Saggers S. 6.7 The Evidence Base for Responding to Substance Misuse in Indigenous Minority Populations. Preventing harmful substance use: the evidence base for policy and practice 2005:381.

3. Lander F, Gray D, Wilkes E. The Alcohol Mandatory Treatment Act: evidence, ethics and the law. Med J Aust 2015;203:47-9.

4. Wood DS. Explanations of employment turnover among Alaska village public safety officers. J Crim Justice 2002;30:197-215.

5. United Nations. Implementing the UN Declaration on the Rights of Indigenous Peoples Handbook for Parliamentarians: United Nations. 2014. http://www.un.org/esa/socdev/publications/Indigenous/ Handbook/EN.pdf. Accessed 30 June, 2016.

6. National Aboriginal Community Controlled Health Organisation (NACCHO). Aboriginal Health: NACCHO. 2016. http://www.naccho. org.au/about/aboriginal-health/. 30 June, 2016. Secondary National Aboriginal Community Controlled Health Organisation (NACCHO). Aboriginal Health: NACCHO 2016. http://www.naccho.org.au/about/ aboriginal-health/. 30 June, 2016.

7. Calladine K. Liquor restrictions in Western Australia. Indigenous Law Bulletin 2009;7.11:23.

8. Wood DS, Gruenewald PJ. Local alcohol prohibition, police presence and serious injury in isolated Alaska Native villages. Addiction 2006;101:393-403.

9. Marks-Sultan G, Tsai FJ, Anderson E, et al. National public health law: a role for WHO in capacity-building and promoting transparency. Bull World Health Organ 2016;94:534-9.

10. Health Organization. Indigenous populations: World Health Organization. 2016. http://www.who.int/topics/health_services_ indigenous/en/. (accessed 30 June).

11. Arnold M, Moore SP, Hassler S, et al. The burden of stomach cancer in indigenous populations: a systematic review and global assessment. Gut 2014;63:64-71.

12. Angell B, Muhunthan J, Eades A-M, et al. The health-related quality of life of Indigenous populations: a global systematic review. Qual Life Res 2016;25:2161-78.
13. Margolis SA, Ypinazar VA, Muller R. The impact of supply reduction through alcohol management plans on serious injury in remote indigenous communities in remote Australia: a ten-year analysis using data from the royal flying doctor service. Alcohol Alcohol 2008:43:104-10.

14. Margolis SA, Ypinazar VA, Muller R, et al. Increasing alcohol restrictions and rates of serious injury in four remote Australian Indigenous communities. Med J Aust 2011;194:503-6.

15. Gray D, Saggers S, Atkinson D, et al. Beating the grog: an evaluation of the Tennant Creek liquor licensing restrictions. Aust $N$ Z J Public Health 2000;24:39-44.

16. Chiu AY, Perez PE, Parker RN. Impact of banning alcohol on outpatient visits in Barrow, Alaska. JAMA 1997;278:1775-7.

17. Douglas M. Restriction of the hours of sale of alcohol in a small community: a beneficial impact. Aust $N Z J$ Public Health 1998;22:714-19.

18. Hogan E, Boffa J, Rosewarne C, et al. What price do we pay to prevent alcohol-related harms in Aboriginal communities? The Alice Springs trial of liquor licensing restrictions. Drug Alcohol Rev 2006;25:207-12.

19. May PA. Arrests, alcohol, and alcohol legalization among an American Indian tribe. Plains Anthropologist 1975:129-34.

20. Schechter EJ. Alcohol rationing and control systems in Greenland. Contemp. Drug Probs 1986;13:587.

21. Wood DS. Alcohol controls and violence in Nunavut: a comparison of wet and dry communities. Int J Circumpolar Health 2011;70:19-28.

22. Berman M, Hull T, May P. Alcohol control and injury death in Alaska Native communities: wet, damp and dry under Alaska's local option law. J Stud Alcohol 2000;61:311-19.

23. Landen MG. Alcohol-related Mortality and Tribal Alcohol Legislation. $J$ Rural Health 1997:13:38-44.

24. Landen MG, Beller M, Funk E, et al. Alcohol-related injury death and alcohol availability in remote Alaska. JAMA 1997;278:1755-8.

25. Lee N. Differential deviance and social control mechanisms among two groups of Yup'ik Eskimo. Am Indian Alsk Native Ment Health Res 1993;5:57-72.

26. Berman M. Suicide among young Alaska Native men: community risk factors and alcohol control. Am J Public Health 2014;104(Suppl 3):S329-35.

27. Gallagher MM, Fleming DW, Berger LR, et al. Pedestrians and hypothermia deaths among Native Americans in New Mexico. JAMA 1992;267:1345-8.

28. Ellis $\mathrm{BH}$. Mobilizing communities to reduce substance abuse in Indian country. J Psychoactive Drugs 2003;35:89-96.

29. d'Abbs $\mathrm{PH}$. Out of sight, out of mind? Licensed clubs in remote aboriginal communities. Aust NZ J Public Health 1998;22:679-84.

30. Clough AR, Margolis SA, Miller A, et al. Alcohol control policies in Indigenous communities: a qualitative study of the perceptions of their effectiveness among service providers, stakeholders and community leaders in Queensland (Australia). Int J Drug Policy 2016;36:67-75

31. Boffa J, Rosewarne C. Alcohol and Alice Springs: meeting the needs and wishes of the community. Indigenous Law Bulletin 2003;5:11

32. Brady M, Byrne J, Henderson G. 'Which Bloke Would Stand Up for Yalata?': the Struggle of an Aboriginal Community to Control the Availability of Alcohol. Australian Aboriginal Studies 2003;62-71.

33. Abimbola S. The information problem in global health.

34. Gracey M, King M. Indigenous health part 1: determinants and disease patterns. Lancet 2009;374:65-75.

35. King M, Smith A, Gracey M. Indigenous health part 2: the underlying causes of the health gap. Lancet 2009;374:76-85

36. d'Abbs $P$. Widening the gap: the gulf between policy rhetoric and implementation reality in addressing alcohol problems among Indigenous Australians. Drug and Alcohol Review 2015;34:461-6. 